\title{
PELAYANAN ADMINITRASI DI KANTOR KEPENGHULUAN MENGGALA SEMPURNA KECAMATAN TANAH PUTIH, KABUPATEN ROKAN HILIR
}

\section{ADMINISTRATION SERVICES AT MENGGALA SEMPURNA VILLAGE, TANAH PUTIH, ROKAN HILIR DISTRICT}

\author{
Siti Rusma, Ulung Pribadi \\ FISIPOL, Universitas Muhammadiyah Yogyakarta \\ @titiansyahri20@gmail.com, ulungpribadi@gmail.com
}

\begin{abstract}
Abstrak
Penelitian ini bertujuan untuk mengetahui pelayanan di kantor penghulu menggala sempurna kepada masyarakat dan juga untuk mengetahui hambatan-hambatan dari pelayanan pengurusan Surat Pengantar KTP di Kantor Kepenghuluan Menggala Sempurna Kecamatan Tanah Putih Kabupaten Rokan Hilir. Metode penelitian yang penulis gunakan ialah kuantitatif dengan format deskriptif yang menggunakan analisis wawancara mendalam dengan beberapa pegawai dan juga menggunakan quisioner sebagai tekhnik pengumpulan data. Hasil penelitian yang penulis lakukan dapat disimpulkan bahwa Analisis Pelayanan di Kantor Kepenghuluan Menggala Sempurna Kecamatan Tanah Putih Kabupaten Rokan Hilir, khususnya pelayanan pengurusan Surat Pengantar KTP yaitu "Cukup Baik". Hal ini didasarkan dari 5 indikator penelitian, yaitu indikator Tangibles, Reability, Responsive, Asurance, dan Emphaty, yang ternyata sebagian besar berada pada kategori Cukup Baik. Meskipun terdapat Beberapa hambatan antara petugas dalam memberikan pelayanan kepada masyarakat terhambat oleh sarana prasarana yang ada, dan adanya sikap diskriminasi dari perangkat pegawai dalam melayani masyarakat.
\end{abstract}

Kata Kunci: kepuasan masyarakat; Pelayanan Publik; pelayanan administrasi

\begin{abstract}
This study aims to find out the service at the office of the superior gala pengala to the public and also to find out the obstacles of the service of arranging a KTP Cover Letter in the Penggala Perfect Kepenghuluan Office, Tanah Putih District, Rokan Hilir Regency. The research method that I use is quantitative with a descriptive format that uses in-depth interview analysis with several employees and also uses questionnaires as data collection techniques. The results of the research that the author did can be concluded that the Analysis of Services at the Office of the Perfect Gala Kepenghuanuan Subdistrict Tanah Putih, Rokan Hilir Regency, especially the management services of a KTP Cover Letter is "Good Enough". This is based on 5 research indicators, namely Tangibles, Reability, Responsive, Asurance, and Emphaty indicators, which turned out to be mostly in the Fairly Good category. Although there are some barriers between officers in providing services to the community hampered by existing infrastructure, and there is an attitude of discrimination from the apparatus of employees in serving the community.
\end{abstract}


Keywords: administration service; community satisfaction; public services

\section{Pendahuluan}

Pada dasarnya setiap manusia membutuhkan pelayanan, dan secara ekstrim dapat dikatakan bahwa pelayanan tidak dapat dipisahkan dari kehidupan manusia. Hal senada juga dikemukakan oleh Budiman Rusli yang berpendapat bahwa selama hidupnya, manusia selalu membutuhkan pelayanan. Pelayanan pengurusan Surat Pengantar KTP, adalah pelayanan yang sangat penting akan memenuhi kebutuhan masyarakat berupa transaksitransaksi yang membutuhkan KTP untuk tanda identitas kependudukan. Setiap Pelayanan Publik dan Penyelenggaraan dalam menyelenggarakan pelayanan publik harus berperilaku sebagai berikut: (1) Tangkas, cermat dan tepat dalam melaksanakan pelayanan; (2) Menunjukan sikap empati terhadap persoalan pemohon informasi, bersikap santun dan ramah; (3) Professional, tidak mempersulit membuka diri terhadap kritik, protes, keluhan, serta keberatan dari permohonan informasi.

Desa merupakan unsur bagian dari pemerintahan kabupaten/kota yang mempunyai tugas pembantu camat dalam melaksanakan kewenangan pemerintah yang dilimpahkan oleh walikota. Dalam Peraturan Daerah Kabupaten Rokan Hilir No.04 Tahun 2018 Tentang Kepenghuluan adalah kesatuan masyarakat hukum yang memiliki batas wilayah yang berwenang untuk mengatur dan mengurus urusan pemerintahan, kepentingan masyarakat setempat berdasarkan prakarsa masyarakat, hak asal usul, dan hak tradisional yang diakui dan dihormati dalam sistem pemerintahan Negara Kesatuan Republik Indonesia. Dalam penyelenggaraan pemerintahan penghulu dibantu perangkat kepenghuluan sebagai unsur penyelenggaraan pemerintahan kepenghuluan. Perangkat kepenghuluan adalah aparatur pemerintahan kepenghuluan yang membantu penghulu dalam melaksanakan tugas dan wewenang yang terdiri atas Sekretaris Kepenghuluan, Pelaksana Kewilayahan dan Pelaksana Teknis. Pelaksanaan kewilayahan atau disebut juga Dusun. Staf adalah perangkat kepenghuluan yang bertugas membantu perangkat kepenghuluan yang menduduki jabatan sesuai dengan tugas pokok dan fungsinya.

Dalam memberi pelayanan oleh aparatur kepenghuluan Menggala Sempurna Kecamatan Tanah Putih Kabupaten Rokan Hilir kepada masyarakat masih terdapat beberapa kendala dalam melaksanakan tugas pemerintahan. Hal ini dapat di lihat dari fenomena yang ditemukan dilapangan, yaitu:

1. Ketidakjelasan jangka waktu penyelesaian, sehingga dalam pengurusan surat pengantar KTP yang seharusnya bisa diselesaikan dalam satu hari tetapi waktu penyelesaianya bisa 3 hari bahkan lebih. 
2. Masih rendahnya pemahaman pegawai dalam menggunakan teknologi seperti komputer, akibatnya penyelesaian pelayanan kepada masyarakat pada masing-masing bidang pekerjaan menjadi lambat, hal ini membuktikan kinerja yang buruk.

3. Terjadi peraturan pemerintah pusat tentang biaya administrasi yang dahulu membayar dan sekarang ditiadakan/gratis.

4. Adanya tindakan diskriminatif yang dilakukan oleh staf perangkat penghulu.

Adapun jenis pelayanan umum yang diberikan oleh Kepenghuluan Menggala Sempurna Kecamatan Tanah Putih Kabupaten Rokan Hilir kepada masyarakat antara lain Pelayanan Administrasi seperti Surat Pengantar KTP, dan KK, Surat Keterangan Kelahiran, SKGR Tanah dan Surat Nikah; dan Pelayanan Rekomendasi Perizinan IMB dan SITU sifatnya hanya memberikan surat pengantar untuk diteruskan kepada instansi yang terkait. Setiap hari masyarakat yang dilayani mencapai 15 orang bahkan lebih jika terjadi pelonjakan yang siknifikan sedangkan jumlah pegawai yang ada di kantor tersebut tidak seimbang dengan yang menerima pelayanan. Dalam penelitian ini penulis ingin mengetahui dan menjelaskan bagaimana seorang pegawai memberikan pelayanan di kantor Penghulu Menggala Sempurna Kecamatan Tanah Putih Kabupaten Rokan Hilir dalam pengurusan Surat pengantar KTP. Pelayanan administrasi surat Pengantar KTP adalah pelayanan yang sangat penting akan memenuhi kebutuhan masyarakat berupa transaksitransaksi yang membutuhkan KTP untuk tanda identitas kependudukan.

\section{Metode Penelitian}

Penelitian ini adalah penelitian survey. Sedangkan metode penelitian yang penulis gunakan ialah kuantitatif dengan format deskriptif. Penelitian kuantitatif dengan format deskriptif bertujuan untuk menjelaskan, meringkas berbagai kondisi, berbagai situasi, atau berbagai variable yang timbul di masyarakat yang menjadi objek penelitian itu berdasarkan apa yang terjadi (Burhan, 2013).

\section{Hasil dan Pembahasan}

Analisis Pelayanan di Kantor Kepenghuluan Menggala Sempurna Kecamatan Tanah Putih Kabupaten Rokan Hilir

Undang-Undang Nomor 25 Tahun 2009 Tentang Pelayanan Publik tepatnya pasal 1 Ayat 1 menjelaskan bahwa, pelayanan publik adalah kegiatan atau rangkaian kegiatan dalam rangka pemenuhan kebutuhan pelayanan sesuai dengan peraturan perundangundangan bagi setiap warga Negara dan penduduk atas barang, jasa, dan atau pelayanan administratif yang disediakan oleh penyelenggara pelayanan publik. 
Pelayanan publik menjadi sorotan apakah instansi tersebut sudah dikelola dengan baik atau belum. Kualitas pelayanan kepada masyarakat (publik) seringkali merupkan tolak ukur keberhasilan suatu organisasi atau instansi pemerintahan. Pemerintahan harus senantiasa mampu menyediakan pelayanan dengan kualitas yang mendekati harapan masyarakat. Meskipun penyedian pelayanan publik merupakan suatu kewajiban yang harus dilakukan oleh pemerintah sebagai penyelenggara negara. Akan tetapi kewajiban penyedian pelayanan tersebut masih belum dapat memberikan kepuasan bagi masyarakat penggunanya. Pemberian pelayanan umum oleh aparatur pemerintahan kepada masyarakat adalah merupakan perwujudan dari fungsi aparatur Negara sebagai abdi masyarakat, agar tercipta keseragamaan pola, tingkah dan langka dibidang pelayanan umum oleh aparatur pemerintah. Untuk itu perlu adanya suatu landasan dasar atau pola dasar yang bersifat umum dalam bentuk pemberian pelayanan prima atau pelayanan maksimal kepada masyarakat.

Berdasarkan Undang-Undang Nomor 6 Tahun 2014 tentang Desa bahwasanya desa atau sebutan nama lain yang dipimpin oleh kepala desa, yang diangkat oleh bupati/walikota yang berasal dari pegawai negri sipil yang menguasai pengetahuan di bidang teknis pemerintahan. Selanjutnya pada pasal 4 Ayat (1) Peraturan Pemerintah Kabupaten Rokan Hilir Nomor 04 Tahun 2018 Tentang Struktur Organisasi Tata Kerja Pemerintah Kepenghuluan, menerangkan bahwa Penghulu mempunyai tugas;

1. Pelaksanaan Kegiatan Pemerintahan Kepenghuluan

2. Pemberdayaan Masyarakat

3. Pelayanan Masyarakat

4. Penyelenggara Ketentramaan dan Ketertiban Umum

5. Melaksanakan Pembangunan

Pelayanan yang cepat, mudah dan tidak berbelit-belit ketika sedang mengurus surat atau yang berhubungan dengan pelayanan di kantor kepenghuluan ialah sesuatu yang diinginkan oleh setiap warga. Saat ini kantor Kepenghuluan Menggala Sempurna berusaha semaksimal mungkin setiap pelayanan yang dibutuhkan oleh warga dengan tujuan supaya warga sekitar yang berada di Kepnghuluan tersebut bisa merasa mudah. dengan demikian, warga bisa merasa puas dengan pelayanan yang ada di kantor kepenghuluan tersebut.

Untuk mengetahui Pelayanan di Kepenghuluan Menggala Sempurn Kecamatan Tanah Putih Kabupaten Rokan Hilir, maka dapat dilihat dari beberapa indikatornya diantaranya sebagai berikut yaitu:

\section{Tangibles}

Tangibles adalah suatu kemampuan organisasi dalam menunjukan eksistensi kepada pihak eksternal, penampakan fisik, sarana dan prasarana organisasi merupakan bukti nyata dari 
pelayanan yang diberikan oleh penyelenggara dalam hal ini Kantor Penghulu Menggala Sempurna yang meliputi sarana fisik perkantoran, komputerisasi mesin ketik, toilet, ruan tunggu, tempat untuk beribadah dan tempat parkir.

Berdasarkan hasil wawancara penulis Juli 2018 dengan penghulu Menggala Sempurna dikatakan:

"Kami sebagai aparat pemerintahan sudah memberikan pelayanan yang terbaik kepada masyarakat dan apa bila ada kesalahan dalam pelayanan itu tak lepas dari ke khilafan kita sebagai manusia, untuk pelayanan pengurusan Surat Pengantar KTP, sudah maksimal kami lakukan, bukan hanya dipelayanan pengurus surat pengantar KTP saja, namun dibidang pelayanan lain pun sudah kami layanan dengan baik. Ini juga didukung dengan adanya tata ruang dan saran dan prasarana di kantor yang memadai, sehingga masyarakat yang melakukan pengurusan menjadi lebih nyaman".

Selanjutnya berdasarkan hasil pengamatan (Observasi) dilapangan yang penulis lakukan, namun masih terdapat sampah disekitar kantor penghulu, namun yang perlu diperhatikan adalah fasilitas dan sarana prasarana yang ada di kantor penghulu menggala sempurna yang masih belum memadai seperti ruang tunggu, dari hasil observasi yang penulis lakukan terlihat kursi tunggu yang diperuntukan kepada masyarakat jumlahnya sangat sedikit, sehingga banyak masyarakat yang sedang melakukan pengurusan terpaksa berdiri karena tidak kebagian tempat duduk. Kemudian tidak adanya mesin genset atau listrik cadangan, sehingga menghambat proses pelayanan ketika pematian listrik secara bergilir.

Selanjutnya jawaban responden penelitian dari unsur masyarakat, dapat dianalisis dan ditarik kesimpulanya bahwa Pelayanan di Kantor Penghulu Menggala Sempurna Kecamatan Tanah Putih Kabupaten Rokan Hilir dilihat dari hal Tangibles berada pada kategorei "Cukup Baik" dengan persentase 9 Namun yang perlu diperhatikan oleh kepenghuluan menggala sempurna adalah fasilitas ruang tunggu, yang mana hanya ada 3 kursi saja. Ini dianggap belum memadai. Dari observasi yang penulis lakukan saat penelitian memang masih terdapat sampah-sampah yang berserakan di sekitar kantor penghulu, kemudian memang masih kurang lengkapnya sarana dan prasarana di kantor penghulu menggala sempurna, dimana hanya terdapat 3 kursi diruang tunggu dan satu computer dan mesin ketik yang sering rusak saat digunakan dan tidak adanya listrik cadangan (mesin genset) ini mengakibatkan terhambatnya proses pelayanan kepada masyarakat ketika pemadaman listrik secara bergilir. Ini dianggap belum memadai.

\section{Reability}


Reability adalah kemampuan organisasi dalam hal ini kepenghuluan menggala sempurna kecamatan tanah putih kabupaten rokan hilir untuk memberikan pelayanan sesuai yang telah dijanjikan secara akurat dan terpercaya, pelayanan harus sesuai dengan harapan masyarakat yang berarti ketepatan waktu, pelayanan yang sama untuk semua masyarakat tanpa kesalahan.

Berdasarkan hasil wawancara penulis Juli 2018 dengan Sekretaris Kepenghuluan Menggala Sempurna, diperoleh informasi:

"bahwasanya petugas Kepenghuluan Menggala Sempurna sudah menyelesaikan pelayanan pengurusan surat pengantar KTP dengan tepat waktu dan hasil dari pelayanan tersebut juga sudah diterima oleh masyarakat dengan tepat waktu, namun jika ada permaslahan ataupun kendala yang dihadapi masyarakat dalam pengurusan surat pengantar KTP kami selaku pihak Kepenghuluan Menggala Sempurna yang memberikan layanan, siap untuk menyelesaikan permaslahan ataupun kendala-kendala yang dihadapi oleh masyarakat dalam pengurusan tersebut secara baik dan musyawarah".

Tanggapan jawaban responden penelitian dari unsur masyarakat, dapat dianalisis dan ditarik kesimpulan bahwasanya Pelayanan di Kantor Penghulu Menggala Sempurna Kecamatan Tanah Putih Kabupaten Rokan Hilir dilihat dari tabel hal Reability berada pada kategori "Tidak Baik" dengan persentase 57,1\%. Berdasarkan hasil observasi/pengamatan langsung yang penulis lakukan pada lokasi penelitian, mengenai pelaksanaan pelayanan pengurusan surat pengantar KTP di Kepenghuluan Menggala Sempurna Kecamatan Tanah Putih Kabupaten Rokan Hilir, penulis melihat bahwasanya petugas Kepenghuluan Menggala Sempurna belum tepat waktu dalam menyelesaikan pelayanan pengurusan surat Pengantar KTP, sesuai dengan kesepakatan, dan hasil layanan tersebut juga tidak ditermia masyarakat dengan tepat waktu, hal ini penulis lihat dari kurangnya kecakapan petugas dalam melaksanakan tugasnya serta rendahnya disiplin petugas dalam menyelesaikan pelayanan tersebut, karena sebagian petugas masih banyak yang menundah pekerjaanya dengan berbagai alasan untuk menyelesaikan pengurusan surat pengantar KTP tersebut.

\section{Responsivitas}

Tanggapan Responden Penelitian dar Unsur (Pegawai) mengenai Analisis Pelayanan di Kantor Penghulu Menggala Sempurna Kecamatan Tanah Putih Kabupaten Rokan Hilir dilihat dari hal Responsivitas. Berdasarkan hasil wawancara penulis kepada seksi Pemerintahan mengatakan 
"Kami sebagai pegawai kepenghuluan menggala sempurna selalu siap menerima keluhan dan aspirasi dari masyarakat yang sedang melakukan pelayanan surat pengantar KTP dan pelayanan umum lainya”.

Berdasrkan hasil observasi penulis dilapangan mendapakan informasi bahwa pegawai kepenghuluan menggala sempurna kecamatan tanah putih kabupaten rokan hilir kurang respon terhadap masyarakat yang kebingungan mengenai syarakat dan mekanisme procedure dalam melakukan pengurusan pelayanan surat pengantar KTP dan pelayanan lainya. dan pegawai kepenghuluan menggala sempurna tidak respect terhadap keluhan masyarakat, disaat masyarakat mengeluhi mengenai biaya maupun waktu penyelesaian dokumen, pegawai kepenghuluan menggala sempurna tidak peduli akan keluhan tersebut.

Tanggapan jawaban responden penelitian unsur masyarakat, dapat dianalisis dan ditarik kesimpulan bahwasanya Pelayanan di Kantor Penghulu Menggala Sempurna Kecamatan Tanah Putih Kabupaten Rokan Hilir dilihat dari hal Responsivitas berada pada kategori "Cukup Baik" dengan persentase 50,6\%.

\section{Asurance}

Hasil wawancara penulis dengan Sekretaris Penghulu Menggala Sempurna Kecamatan Tanah Putih Kabupaten Rokan Hilir mengatakan, "Saya sebagai Sekretaris Penghulu menggala sempurna telah melayani masyarakat dengan sopan santun ramah dalam bertuturkata, saya sigap dan tanggap atas keluhan masyarakat".

Dari Observasi penulis lakukan di lokasi penelitian yakni kantor penghulu menggala sempurna kecamatan tanah putih kabupaten rokan hilir, memang terlihat ada masyarakat yang mengeluhkan atas sikap-sikap yang ditunjukan oleh pegawai dalam melayani masyarakat,seperti kurang ramahnya pegawai dalam memberikan pelayanan kepada masyarakat, hal seperti ini harusnya tidak terjadi dalam memberikan pelayanan kepada masyarakat karena pegawai ialah abdi negara yang tugasnya memberikan pelayanan yang maksimal kepada masyarakat.

Tanggapan jawaban responden penelitian dari unsur masyarakat, dapat dianalisis dan ditarik kesimpulan bahwasanya Aanalisis Pelayanan di Kantor Penghulu Menggala Sempurna Kecamatan tanah Putih kabupaten Rokan Hilir dilihat dari hal Asurance berada pada kategori "Cukup Baik" dengan persentase 43,6\%. Hasil observasi penulis di lokasi penelitian mendapatkan informasi bahwa juga terlihat adanya krang perduli dan ramah terhadap masyarakat yang sedang melakukan pengurusan. Seharusnya sebagai aparat pemerintahan pegawai harus lebih aktif dan cepat tanggap terhadap apa yang diinginkan masyarakat, sehingga pelayanan yang diberikan dapat terlaksana dengan cepat dan baik.

\section{Empathy}


Berdasarkan hasil wawancara penulis dengan Kaur Pemerintahan Kepenghuluan Menggala Sempurna Kecamatan Tanah Putih Kabupaten Rokan Hilir mengatakan "Kami sudah bekerja dengan baik dan memberikan pelayanan sebaik mungkin kepada masyarakat, dan dalam melayani masyarakat kami tidak ada membeda bedakan satu sama lain semua kami anggap sama dalam memberikan pelayanan dan jika ada sikap diskriminasi yang dilakukan pegawai terhadap masyarakat silahkan dilapornakn dan kami akan ambil tindakan berupa teguran sebagai efek jera.

Jadi jawaban responden penelitian dari unsur masyarakat, dapat dianalisis dan ditarik kesimpulan bahwasanya Analisis Pelayanan di Kantor Penghulu Menggala Sempurna Kecamatan Tanah Putih Kabupaten Rokan Hilir dilihat dari hal Empathy berada pada kategori "Tidak Baik" dengan persentase 43,2\%. Hasil wawancara penulis kepada masyarakat yang pernah mengurus surat pengantar KTP mengatakan:

"Kami sungguh kesal dengan sikap pegawai kepenghuluan menggala sempurna ada beberapa pegawai yang membedakan pelayanan kepada masyarakat, dimana masyarakat lain yang membayar lebih atau membayar penuh biaya administrasi pengurusan surat pengantar KTP tersebut, maka masyarakat tersebut akan didahulukan waktu penyelesaian dokumenya, sedangkan yang tidak membayar maka akan lambatlah selesainya”.

Adapun analisis penulis dari hasil rekapitulasi jawaban keseluruhan responden berdasarkan masing-masing indikator di atas mengenai Pelayanan Di kantor Penghulu Menggala Sempurna Kecamatan Tanah Putih Kabupaten Rokan Hilir khususnya pelayanan pembuatan/pengurusan surat Pengantar KTP, penulis menilai masih belum terlaksana dengan baik. Hal ini penulis lihat dari hasil penyebaran koesioner dan /pengamatan langsung yang penulis lakukan pada lokasi penelitian, serta didukung dengan hasil wawancara penulis dengan beberapa responden, yang mana petugas yang diberi kewenangan untuk memberikan pelayanan kepada masyarakat kurang efektif dalam melaksanakan tugasnya, kemudian sebagian petugas yang masih menunggu instruksi dari atasanya, hal ini yang menjadi penghambat pelayanan di Kepnghuluan tersebut. Selanjutnya dalam proses penyelesaian pelayanan juga tidak tepat waktu, sedangkan waktu penyelesaian tersebut sudah disepakati bersama, hal ini dikarenakan kurangnya sumber daya petugas di Kepenghuluan Menggala. Kemudian, kurangnya kejelasan administrasi pengurusan surat pengantar KTP, petugas juga tidak adil dalam menetapkan biaya administrasi dan jangka waktu penyelesaianya dokumken tersebut, jika yang melakukan pengurusan tersebut kerabat atau keluarganya, maka waktu penyelesaian dokumenya akan terselesaikan dengan cepat. Selanjutnya dalam hal sarana prasarana yang ada di Kepenghuluan Menggala Sempurna juga tergolong minim, hal ini dilihat dari sarana yang 
ada yaitu 1 unit computer dan mesin ketik yang sering rusak saat digunakan dan tidak adanya listrik cadangan (mesin Genset) ketika pematian listrik secara bergilir, akan menghambat proses pelayanan kemudian sedikitnya kursi ruang tunggu sehingga ada masyarakat yang berdiri karena tidak kebagian tempat duduk, serta toilet dan ruangan sholat yang tidak memadai.

\section{Hambatan Pelayanan Di kantor Penghulu Menggala Sempurna Kecamatan Tanah Putih Kabupaten Rokan Hilir}

1. Petugas Kepenghulan Menggala Sempurna Kecamatan Tanah Putih Kabupaten Rokan Hilir dalam memberikan pelayanan kepada masyarakat selalu terhambat oleh sarana prasarana yang ada, karena sarana yang ada tidak memadai dan masih kurang dalam menunjang pelayanan diKepenghuluan Menggala Sempurna. Hal inilah yang menjadi penghambat petugas dalam memberikan pelayanan.

2. Sikap diskriminasi dalam pelayanan pengurusan surat pengantar KTP, dimana adanya perbedaan yang diperlihatkan oleh pegawai terhadap masyarakat yang melakukan pengurusan Surat Pengantar KTP. Perbedaan ini terlihat dari masyarakatr yang memiliki hubungan kedekatan (kerabat/saudara) dan masyarakat yang membayar secara penuh dengan petugas maka itu yang didahulukan.

3. Berdasarkan wawancara dengan Penghulu mengatakan, yang menjadi hambatan utama dalam pengurusan surat pengantar KTP yaitu mesin komputer yang tidak berjalan dengan baik.

\section{Penutup}

Dari hasil penelitian yang penulis lakukan dapat disimpulkan bahwa Analisis Pelayanan di Kantor Kepenghuluan Menggala Sempurna Kecamatan Tanah Putih Kabupaten Rokan Hilir, khususnya pelayanan pengurusan Surat Pengantar KTP yaitu "Cukup Baik". Hal ini didasarkan dari 5 indikator penelitian, yaitu indikator Tangibles, Reability, Responsive, Asurance, dan Emphaty, yang ternyata sebagian besar berada pada kategori Cukup Baik.

Adapun yang menjadi hambatan dalam Analisis Pelayanan di Kantor Kepenghuluan Menggala Sempurna Kecamatan Tanah Putih Kabupaten Rokan Hilir, khususnya dalam pelayanan pengurusan Surat Pengantar KTP yaitu antara lain:

a. Petugas Kepenghuluan Menggala Sempurna Kecamatan Tanah Putih kabupaten Rokan Hilir dalam memberikan pelayanan kepada masyarakat selalu terhambat oleh sarana prasaranan yang ada, karena sarana yang ada tidak memadai dan masih kurang dalam menunjang pelayanan kepada masyarakat di Kepenghuluan Menggala sempurna. Hal inilah yang menjadi penghambat petugas dalam memberikan pelayanan. 
b. Hambatan selanjutnya adalah terlihat dari sikap perangkat pegawai dalam melayani masyarakat yang kurang ramah, cuek, kurangnya responsive dari perangkat penghulu ketika masyarakat mengeluh akan pelayanan yang diberikan oleh perangkat penghulu kelurahan menggala sempurna kecamatan tanah putih kabupaten rokan hilir.

c. Yang paling disoroti masyarakat pada Kantor Penghulu Menggala Sempurna Kecamatan Tanah Putih Kabupaten Rokan Hilir yaitu sikap diskriminasi dalam pelayanan pengurusan surat Pengantar KTP, perbedaan ini terlihat dari masyarakat yang memiliki hubungan kedekatan (kerabat) dan masyarakat yang membayar penuh biaya administrasinya maka itu yang akan didahulukan.

Saran yang dapat penulis berikan antara lain:

1. Mengenai saran dan prasarana di kantor Kepenghuluan Menggala Sempurna Kecamatan Tanah Putih Kabupaten Rokan Hilir sebaiknya melengkapi sarana dan prasarana tersebut, seperti ruang tunggu dan toilet yang kurang memadai, serta tidak adanya ruang ibadah, Sebaiknya Penghulu Menggala Sempurna lebih sering melihat bagaimana pelayanan yang diberikan oleh bawahanya terhadap masyarakat, dan bagi yang tidak memberikan pelayanan yang baik seperti tidak ramah, cuek kurang responsive kepada masyarakat harus tegur atau tindakan tegas supaya ada efek jera sehingga kedepanya bisa berubah dan dapat memberikan pelayanan yang maksimal kepada masyarakat.

2. Petugas harus menyelesaikan hasil pelayanan tersebut sesuai dengan waktu yang telah disepakati, agar masyarakat merasakan kepuasan pelayanan yang diberikan kepada perangkat penghulu.

3. Kemudian mengenai rincian biaya yang harusnya gratis dan tidak ada pemungutan biaya mengatasnamakan biaya administrasi dan biaya uang jalan tersebut harus ditiadakan agar terlaksananya Standart Operasional Prosedur (SOP) yang berlaku di kantor penghulu menggala sempurna.

4. Dan yang paling utama tidak ada lagi tindakan diskriminatif atau membeda-bedakan antara masyarakat yang menerima pelayanan di kantor tersebut.

\section{Daftar Pustaka}

Burhan, Bungin, 2013. Metode Penelitian Sosial dan Ekonomi. Jakarta. Kencana

Rusli Budiman, 2004, Pelayanan Publik diera Reformasi, Teropong, Bandung

Peraturan Daerah Kabupaten Rokan Hilir No.04 Tahun 2018 Tentang Kepenghuluan

Peraturan Pemerintah Kabupaten Rokan Hilir Nomor 04 Tahun 2018 Tentang Struktur Organisasi Tata Kerja Pemerintah Kepenghuluan 
Undang-Undang Nomor 25 Tahun 2009 Tentang Pelayanan Publik

Undang-Undang Nomor 6 Tahun 2014 tentang Desa 